\title{
Isolation of the Peroxisomal Core from Rat Liver and Its Identification as Uricase
}

\author{
Kazuhisa Nakashima, Satoko Fujiwara and Sueko Hayashi \\ Department of Biochemistry (Chief : Prof. Tomoo Noguchi) \\ Kyushu Dental College, Kitakyushu, Japan
}

Received on June 15, 1988

\begin{abstract}
Key words : Peroxisome/Peroxisomal core/Uricase/Rat liver/Sucrose-densitygradient centrifugation
\end{abstract}

\section{Introduction}

The degradation of purines to urate is common to all animal species, whereas the degradation of urate is much less complete in higher animals ${ }^{1)}$. Enzymes involved in the degradation of purines to urate are located in the cytosol in marine fish, and those of urate to urea and glyoxylate are in the peroxisomes, suggesting that in purine metabolism, peroxisomal enzymes, e.g. uricase (EC 1.7.3.3), allantoinase (EC 3.5.2. 5), and allantoicase (EC 3.5.3.4) have been lost during evolution ${ }^{2 \sim 4)}$.

Uricase catalyses the initial reaction in the degradation of urate and exists as the insoluble form (core) in the peroxisomes of mammalian liver. Crystals of isolated uricase from hog liver are similar to the peroxisomal core in the electron microscopic feature, suggesting that the core consists of uricase exclusively ${ }^{5)}$. However, the peroxisomal core has been reported to be composed of uricase and other proteins ${ }^{6 \sim 8)}$. Watanabe et al. ${ }^{9}$ ). isolated the peroxisomal core from rat liver by minor modification of the method of Tsukada et al. ${ }^{10)}$. and claimed that the core was composed of uricase and a frame protein with a molecular weight of 27,000. In contrast, Antonenkov and Panchenko ${ }^{11)}$ also isolated the core from rat liver by a similar method, suggesting that the core contained only uricase molecules. However, the isolation method of the core used in this study is based on its detergent insolubility. Furthermore, they examined the constituents of the isolated core by sodium dodecyl sulfate polyacrylamide gel electrophoresis after its gel filtration. In this method, the core-associated proteins other than uricase may be removed by repeated detergent treatments of the core and its gel filtration. Therefore, a new isolation method of the core is necessary for the identification of its constituents.

The present report describes a rapid isolation method of the peroxisomal core from rat liver without the use of detergents and its identification as uricase itself. 


\section{Materials and Methods}

Peroxisomes were isolated from rat liver by using sucrose density gradient centrifugation in a vertical rotor according to the method of Osmundsen et al. ${ }^{12}$ ). Subsequent procedures were carried out at $0-4^{\circ} \mathrm{C}$. Two milliliters of a peroxisomal suspension ( $2 \mathrm{ml}$ ) from $4 \mathrm{~g}$ of rat liver, free of mitochondrial, lysosomal and microsomal contamination, were diluted with the same volume of $0.01 \mathrm{M}$ pyrophosphate buffer, $\mathrm{pH} 9.0$, which was known to break rat liver peroxisomes ${ }^{7)}$. After being stored overnight, the suspension was layered on a $30 \mathrm{ml}$ discontinuous sucrose density gradient and centrifuged at $132,400 \times g$ for $70 \mathrm{~min}$ with a vertical rotor. The gradient was prepared with the following sucrose solution in a buffer ( $\mathrm{pH}$ 7.4) containing $5 \mathrm{mM} 3^{-}$(N-morpholino) propane-sulfonic acid, 2\% Dextran T 10, $1 \mathrm{mM}$ EDTA and $0.1 \%$ ethanol : $4.5 \mathrm{ml}$ each of $56,49,47,45,42,38$ and $30 \%$. After centrifugation, fractions $(1.6 \mathrm{ml})$ were collected from the bottom of the tube. Core fractions (fractions 1 to 3 ) with uricase activity and without catalase activity were separately diluted with $4 \mathrm{vol}$. of ice cold buffer described above and centrifuged at $52,000 \times g$ for $30 \mathrm{~min}$. Each resulting pellet was subjected to SDS-polyacrylamide gel electrophoresis by the method of Laemmli ${ }^{13)}$. The peroxisomal suspension $(2 \mathrm{ml}$ ) from $4 \mathrm{~g}$ of rat liver was also sonicated at $10 \mathrm{KHz}$ for $15 \mathrm{~s}$ for the disruption of the peroxisomes and subjected to sucrose density gradient centrifugation followed by the electrophoresis as described above.

Catalase and uricase were assayed by the methods previously reported ${ }^{2}{ }^{3}$ ). A unit of enzyme activity is defined as the amount of enzymes that catalyse a decrease in substrate of $1 \mu \mathrm{mol} / \mathrm{min}$ at $37^{\circ} \mathrm{C}$.

\section{Results and Discussion}

Fig. 1 shows the sedimentation profile of the peroxisomes broken by pyrophosphate treatment in a sucrose density gradient. The activity of uricase as the peroxisomal core enzyme was recovered only in the bottom fractions and that of catalase as the peroxisomal soluble matrix enzyme only in the soluble top fractions. This result shows that the peroxisomes were completely broken by their pyrophosphate treatment yielding the complete separation of the core and the soluble matrix. Fig. 2 shows the results of sodium dodecyl sulfate polyacrylamide gel electrophoresis of the core fractions (fractions 1-3 of Fig. 1) from a sucrose density gradient. A single protein band was obtained in each case. When the sonicated peroxisomes were subjected to sucrose density gradient centrifugation followed by the electrophoresis of the core fractions as described above, the same result as for the pyrophosphate treated peroxisomes was obtained.

On the basis of the present results, it is concluded that the peroxisomal core of rat liver is uricase itself. It is well known that in mammalian other than primates, uricase exists as an insoluble form in the peroxisomal core. Recently we found that 


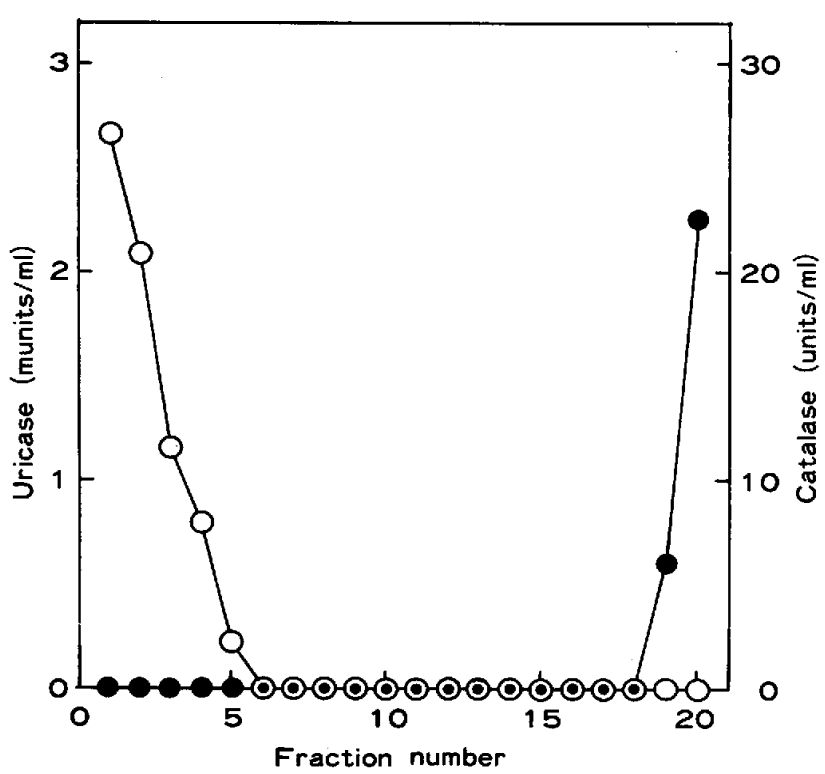

Fig. 1. Sedimentation profile of rat liver peroxisomes broken by pyrophosphate treatment in a sucrose density gradient. Isolated peroxisomes from rat liver were subjected to pyrophosphate treatment and then sucrose density gradient centrifugation with a vertical rotor. After centrifugation, franctions ( $2 \mathrm{ml}$ ) were collected from the bottom. $O$, uricase; catalase.

uricase was also present as an insoluble form in the core of liver peroxisomes in old world monkeys (unpublished data); uricase had not been detected in new world monkeys, great apes and human ${ }^{14)}$. The present method for a rapid isolation of the peroxisomal core would be also usable for mammalian other than rats. It is of interest to determine by the use of the present isolation method whether the peroxisomal core is also uricase itself in all mammalian or not.

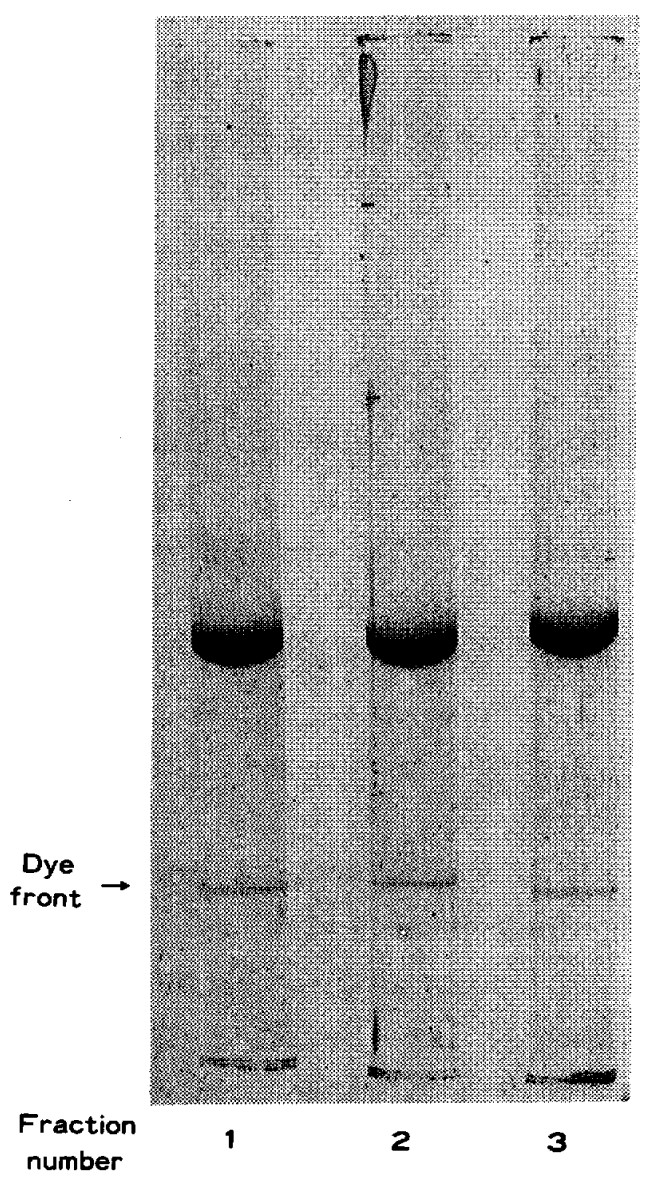

Fig. 2. Sodium dodecyl sulfate polyacrylamide gel electrophoresis of isolated cores from rat liver peroxisomes. Core fractions 1 to 3 from a sucrose density gradient (Fig. 1) were separately subjected to the electrophoresis as described in the text. The migration is from top to bottom. Gels were stained for protein in $0.25 \%$ Coomassie brilant Blue $R 250$ in methanol/acetic acid/ water $(5: 1: 5$, by vol.) and destained by diffusion in $7 \%$ acetic acid.

\section{Summary}

The peroxisomal core was rapidly isolated from rat liver and identified as uricase itself as follows. Rat liver peroxisomes were broken by pyrophosphate treatment or sonication followed by sucrose-density gradient centrifugation. In each case, the cores 
with uricase activity and without catalase activity were recovered in the bottom frcations. Sodium dodecyl sulfate polyacrylamide gel electrophoresis of the cores yielded a single protein band in each case. These data show that the peroxisomal core is uricase itself in rat liver. This rapid isolation method of the peroxisomal core would be also usable for other mammalian.

\section{References}

1) White, A., Handler, P. and Smith, E.L. : Catabolism of purine nucleotides, In : Principles of biochemistry. 5th ed., McGraw-Hill, New York, 1974, 714-719.

2) Noguchi, T., Takada, Y. and Fujiwara, S. : Degradation of uric acid to urea and glyoxylate in peroxisomes. J. Biol. Chem. $254: 5272-5275,1979$.

3 ) Takada, Y and Noguchi, T. : The degradation of urate in liver peroxisomes. Association of allantoinase with allantoicase in amphibian liver but not in fish and invertebrate lver. J. Biol. Chem. $258: 4762-4764,1983$.

4 ) Noguchi, T., Fujiwara, S. and Hayashi, S. : Evolution of allantoinase and allantoicase involved in urate degradation of liver peroxisomes. A rapid purification of amphibian allantoinase and allantoicase complex, its subunit locations of the two enzymes, and its comparison with fish allantoinase and allantoicase. J. Biol. Chem. $261: 4221-4223,1986$.

5 ) Hruban, Z. and Swift, H. : The localization in hepatic microbodies. Science 146:1316-1317, 1964 .

6) Leighton, F., Poole, B., Beaufay, H., Baudhuin, P., Coffey, J.W., Fowler, St, and De Duve, C. : The large-scale separation of peroxisomes, mitochondria, and lysosomes from the livers of rats injected with Triton WR-1339. J. Cell Biol. $37: 482-513,1968$.

7 ) Leighton, F., Poole, B., Lazarow, P.B. and De Duve, C. : The synthesis and turnover of rat liver peroxisomes. I . Fractionation of peroxisome proteins. J. Cell Biol. 41:521535,1969 .

8 Hayashi, H., Suga, T. and Ninobe, S. : Studies on peroxisomes. VI. Relationship between the peroxisomal core and urate oxidase. J. Biochem. $79: 1029-1034,1976$.

9) Watanabe, T., Suga, T. and Hayashi, H. : Studies on peroxisomes. VII. Evidence for framework protein of the cores of rat liver peroxisomes. J. Biochem. $82: 607-609,1977$.

10) Tsukada, H., Mochizuki, Y. and Fujiwara, S. : The nucleoids of rat liver cell microbodies. J. Cell Biol. $28: 449-460,1966$.

11) Antonenkov, V.D. and Panchenko, L.F.: Organization of urate oxidase in peroxisomal nucleoids. FEBS Letters $88: 151-154,1978$.

12) Osmundsen, H., Neat, C.E. and Norum, K.R. : Peroxisomal oxidation of long chain fatty acids. FEBS Letters $99: 292-296,1979$.

13) Laemmli, U.K. : Cleavage of structural proteins during assembly of the head of bacteriophage. T4. Nature $227: 680-685,1970$.

14) Christen, P., Peacock, W.C., Christen, A.E. and Wacker, W.E.C. : Urate oxidase in primates phylogenesis. Eur. J. Biochem. 12:3-5, 1970. 


\title{
ラット肝臓ペルオキシソームのコアの単離と \\ ウリカーゼとしての同定
}

九州歯科大学生化学教室

\author{
中島和久・藤原 智子・林 寿恵子
}

プリンの尿酸までの分解は全動物種に共通して存在す るが，尿酸以降の分解は種により異り，高等動物ほど不 完全である、我々はある種の魯類では，プリンから尿酸 までの分解酵素群がシトソールに存在するのに対し，尿 酸の尿素とグリオキシル酸までの分解酵素群がペルオキ シソームに局在することから, 動物の進化において, ペ ルオキシソームの酵素（ウリカーゼ，アラントイナー ゼ，アラントイカーゼ）が選択的に脱落したことを示唆 してきた.ウリカーゼは尿酸分解系における初発反応を 触媒する . この酵素を持つ哺乳類の肝細胞には, 結晶性 のコア（ヌクレオイド）があり，その組成は未だはっき りしていず，ウリカーゼのみという報告と他のタンパク 質も含まれるという報告がある，本研究はラット肝㵴 からコアを単離し，その組成を明らかにしようとしたも のである．まず，ラット肝臓からペルオキシソームを
Osmundsen らの方法により単離し，その等張䜿濁液を ピロリン酸緩衝液で処理した（等量ピロリン酸- $\mathbf{K O H}$ 緩衝夜を加え, $\mathrm{pH}$ を 9.0 亿調整し $4^{\circ} \mathrm{C}$ で一夜放置). 次にこれをバーチカルローターを用いて, 蕉糖密度勾配 (30\%一 -56\%) 遠心法により分画したとてろ，遠心管の 底部近くに, ウリカーゼ活性を持ち, カタラーゼ活性を 持たないコアが沈降した。そこで，とのコアを集め， SDS-電気泳動を行ったところ, 単一のタンパクバンド が得られた。またペルオキシンームの等張懸濁液を超音 波処理後, 同様に蕉糖密度勾配遠心法により分画したと ころ, 同一の結果が得られた，以上の結果はコアがウリ カ一ゼそのものであることを示している.なお，ての非 常に簡単なコア（ウリカーゼ）の単離法は他の哺乳動物 の肝蔵のコアの単離にも適用できるものと思われる. 